\title{
Political Economy of Communication Policy in Indonesia
}

\author{
Dadang Rahmat Hidayat \\ Faculty of Communication Science \\ Padjadjaran University \\ Jatinangor, Indonesia \\ dadang.rahmat@unpad.ac.id
}

\author{
Wahyuni Choiriyati \\ Doctoral Student of Faculty of Communication Science \\ Padjadjaran University \\ Jatinangor, Indonesia \\ choiri@staff.gunadarma.ac.id
}

\begin{abstract}
Indonesia is a Nation that embraces many different ethnic groups. Each of them has its own customary law, which has been implemented for centuries. Even though Indonesia is regulated by its rules of law, for the private matters, some customary laws and Islamic law are still applicable. Problems are arisen when rules regarding certain things in customary or Islamic laws and national law are conflicting. The solution is usually a traditional approach that put supremacy of national law. Many indigenous people who have bound by their customary law or Islamic law for decades, cannot easily accept enforcement of the national law. Therefore, positivistic approach per se will potentially create more problems. This paper will examine how ethics or morality may play important roles in determining what is the best solution that can maintain the balance of principle of legal certainty and principle of fairness.
\end{abstract}

Keywords - Communication Policy; Political Economy; Hermeneutics

\section{INTRODUCTION}

Problems faced by the world of broadcasting also involves the issuance of foreign capital participation. In accordance with the needs of national investment climate, foreign capital is indispensable in the current national economic conditions. The issue raised is the extent to which the expansion of foreign capital that would be given a room in the National Broadcasting Regulation. It refers to the Broadcasting Act 32 of 2002 Article 15 which allows $20 \%$ of foreign capital participation in the broadcasting company total shares. Obviously the public still clearly remember when Megawati was still serving as a president, she approved the $20 \%$ of foreign capital participation in broadcasting company as written in the clause of Broadcasting Law that had just been legalized. Unfortunately, once again the Broadcasting Act 32 of 2002, which limit the expansion of foreign capital in national broadcasting industry is not sufficient to become a legal umbrella. These opportunities are widely open, when a broadcasting media company go public since foreign investors see great opportunities in the industry to reach a population of 250 million people from all over Indonesia.

Beyond the regulation of broadcasting, people are faced with the problem of implementation of the Law on Electronic Transaction Information No. 11 in 2008. At the beginning of Jokowi era in 2015, 22 suspected radical online sites were blocked by the Ministry of Communication and Information.
Public assess this in conditions that completely gray. Blocking was done with the legal basis of the Law on Information and Electronic Transactions (ITE Law). Ironically, the law did not regulate clearly about the authority of the blocking or filtering of internet sites.

The Law of Information and Electronic Transactions (ITE Law) is actually a form of communication policy. As a communications policy, ITE Law must be able to launch Internet-based communications systems. In line with the explanation of Abrar [1] This is a logical consequence of its position as a communications policy. As described by UNESCO, communication policy is a set of principles and norms that deliberately created to regulate the behavior of communication systems. Communication system according to Abrar can be categorized by geographic region, media used and communication patterns. Especially with regard to communication systems based on the medium used, there are at least four communication systems, namely printed media system, electronic media systems, traditional media systems and interactive media system. This latest system has its own logic. It has its own pattern of relationships with audiences who use and complete the existing communication systems. The problem that arised later, have interactive media policy in Indonesia be the regulator of the real conditions in Indonesia?

ITE Law includes communications policies governing interactive media (Interactive Media often addressed to all the resources available on the internet). ITE Law should help set up a new communication order, characterized by the fact that it is the individuals who set up the traffic information. The prohibition contained in ITE Law denied the nature of the Internet as a medium, making individuals as a control of information and improve the ability to communicate both personally and hiperpersonally. That is to say, the information contained has become information driven by others. Then the public will question; in understanding the formulation of ITE Law, to which direction the domain and the paradigm of the law is enforced?

Begun from the above issues, the authors propose approaches of Political Economy in communication variants. One aspect of Political Economy is Structuration which is now happening in the realm of communication policy in Indonesia. In Structuration, conflicts and polemics between actors confirmed. Of course, the result will be positive when there is 
an understanding on the importance of a fair settlement in managing the system. This paper at once elaborates phases of conflict of interests in the process of the issuance of communication policy, namely, interpret and define hermeneutically the ad hoc team in the House of Representatives (DPR) following all activities and intellectual that give input, process the legislation, by absorbing and combining the good principles in the delivery of a comprehensive communication policy that governs the dynamics of communication activities in each line in Indonesia.

In practical terms, this study needs to be done considering that the media's target audience has a social and cultural sensitivity. Public as audience should ideally be an important slice protected by the policy. This assumption becomes an important issue in the writer's opinion, given the communications policy-making process by the government of course follow the process of public policy making in common: through various stages of formulation. Socially, this article will be helpful to bring awareness to the public that the communication policy will grow even more if we include all subsystems that establish communication. It involves interpersonal communication subsystem, group communication subsystem, to institutional communication subsystem which are loaded with political and ideological compromise structurally.

\section{METHODOLOGY}

According to Ricoeur [2], Palmer [3] in an effort to interpret and provide interpretation of the incoherent content of the law, the authors chose the study of hermeneutics [4]. Approach to the interpretation of this text are the methods and theories regarding the understanding in interpreting the text. include: (1) the comprehension event of the text; (2) the issue which is more directed on understanding and interpretation. This shows that the main idea in Hermeneutics is the understanding of the text.

\section{RESEARCH FINDINGS \& DISCUSSION}

To obtain a more targeted result, this study focuses more on the text of the Broadcasting Act No. 32 of 2002 on Broadcasting Regulation which was officially entered into force on December 28, 2002. Furthermore, according to the formula of Hermeneutical research, the principles of interpretator historicality on the object of study, namely the Act which was also interpret the context of the enactment of Act No. 32. The Context starts from the beginning of the object presents as a part of the structure resulted by agent. Context is interpreted from the broadcast law that not only adopting the network local broadcasting system, but also introducings a semi-independent agency called the Indonesian Broadcasting Commission (KPI) to set the rules of broadcasting in the country.

Presidential Decree that sets the fit and proper test results conducted by the parliament for the members of KPI itself has just came out a day before the deadline stated in Act No 32 .
As the law laid down by the government through a tough process with the industry, Act No. 32 of 2002 mandates that the KPI should be established not later than one year after this Act applied on December 28, 2002. The appointment of KPI members pursue the deadline of December 28, 2013, is a consequence of protracted tension between the system and broadcasters.

Anthony Giddens and Margaret S. Archer described the interplay between structure and agency. That dynamic process for constructing the society was determined by attraction and interplay between structures (including systems, regulation, rule, social class) and agencies (including the actors of social actions, both individually and collectively). This process by Giddens termed "structuration". Following is the interpretation of the Act No. 32 of 2002:

Table 1. Interpretation of Act No. 32 of 2002

\begin{tabular}{|c|}
\hline $\begin{array}{c}\text { Description of Article on } \\
\text { Broadcasting Act No } 32 \text { of } 2002\end{array}$ \\
\hline $\begin{array}{l}\text { 1) Article } 20 \text { declared "private } \\
\text { broadcasting } \\
\text { institutions, radio } \\
\text { broadcasting services and television } \\
\text { broadcasting services each can only } \\
\text { execute one (1) broadcast with } 1 \text { (one) } \\
\text { channels broadcast at } 1 \text { (one) coverage } \\
\text { broadcast area." }\end{array}$ \\
\hline $\begin{array}{l}\text { 2)Article } 55 \text { paragraph (1) "Any } \\
\text { person who violates the provisions } \\
\text { referred to in (chapter 20) are subject } \\
\text { to administrative sanctions." Article } 55 \\
\text { paragraph (2) }\end{array}$ \\
\hline $\begin{array}{l}\text { Administrative sanctions as referred to } \\
\text { in paragraph (1) may include: a written } \\
\text { warning; temporary termination of the } \\
\text { program after a certain stage; limiting } \\
\text { the duration and time of broadcast; } \\
\text { administrative fines; termination of } \\
\text { broadcasting for a certain time; was } \\
\text { not given the extension of broadcast } \\
\text { licenses; revocation of broadcast } \\
\text { licenses. }\end{array}$ \\
\hline $\begin{array}{l}\text { (3), "Further provisions } \\
\text { concerning the procedures and } \\
\text { administrative sanctions referred to in } \\
\text { paragraph (1) and (2) prepared by KPI } \\
\text { together with the Government." }\end{array}$ \\
\hline
\end{tabular}

Interpretation

The new broadcasting regulation is ultimately not able to shift the government as a major regulator in broadcasting.

The social aspect includes the setting of important principles of televisions relationship with their audience, accountability mechanisms to public television is accommodated through public involvement which allows the new mechanism of broadcasting system.

The setting of television program is also directed to be more responsible with the realignment of the broadcasting code of conduct.

Consistency toward a more democratic national broadcasting tested with a complete broadcast Act No. $32 / 2002$ in the form of Government Regulation (PP). This regulation applies as technical guidelines for the implementation of broadcasting. The contents of this regulation include (1) Regulation No. 49 of 2005 regarding the reporting activities of the Foreign Broadcasting Agency; (2) Regulation No 50 of 2002 regarding implementation broadcasting of private broadcasting agency; (3) Regulation No 51 of 2005 regarding the implementation of the Community Broadcasting for Broadcasting Agency; and (4) Regulation No. 52 of 2005 regarding the implementation of the Broadcasting Institute for Subscribed Broadcasting. 
PP No 50 of 2005 contains the conduct of Private Broadcasting Institutions, while regarding capital is stated in chapter IV, the first part which contains shareholdings is article 24 paragraph 2. Through Broadcasting Regulation, it is hard to dispel the impression that the government as a major policy maker has $\mathrm{b}$ a bigger role than that of the Indonesian Broadcasting Commission (KPI). There is another reality that seems interesting to observe that the broadcasting regulation turned out contradictive and is not coherent with the basic law. The public through various media still remember the endless conflict towards the establishment of the Broadcasting law when the companion regulation will be rolled out. The Broadcasting law is the manifestation of the strong position of KOMINFO as a regulator. This means that KPI is not a superbody institution that organizes the world of broadcasting since it has been shifted by KOMINFO. Citing the Wahyuni article $[5]^{7}$ that in fact the government has failed to interpret the spirit of renewal based on the interests of the community and a sense of justice in the Broadcasting law.

The second object of analysis, including the communication policy of inteactive media (interactive media is often addressed to all the resources available on the Internet). This law should help set up a new communication order, characterized by the fact that individuals who organize the traffic information. In terms of historicality, further analysis will review the context of the ITE Law which has not fully accommodated the nature of interactive media. It can be seen from Article 27 Paragraph 1, which prohibits the distribution of information and electronic documents that have a content of violations.

So as part of the interpretation of the text, the understanding of the whole situation raised by the above mentioned ITE Law is required. We will ask, where in fact the direction formulation ITE Law go?, According to Paula Chakravarty and Katherine Sarikakis [6]' the direction of ITE Law formulation can be seen through the context, domains and paradigms used. What is meant by something covering it is political communication policy. This context is very important for communication policy. This context even specify the policy domain of communication. Ideally, the government still must evaluate the ITE Law with model of crossing media. It is given that the resources involved are still in early stages of literacy media to the interpretation of the usage-based media convergence. Here are the results of the interpretation of the ITE Law No. 8 of 2011 which is not in accordance with te reality in community:
Table 2. Interpretation of Act No. 11 of 2008

\begin{tabular}{|c|c|}
\hline $\begin{array}{l}\text { Description of articles in ITE Law } \\
\text { No } 11 \text { of } 2008\end{array}$ & Interpretation \\
\hline $\begin{array}{l}\text { 1) Article } 27 \text { (3) states "Every person } \\
\text { intentionally and without right to } \\
\text { distributing and / or transmitting and / } \\
\text { or making the inaccessibility of } \\
\text { Electronic Information and / or } \\
\text { Electronic Documents which contains } \\
\text { humiliation and / or defamation. Then } \\
\text { it is (article } 27 \text { paragraph 3) will be } \\
\text { sanctioned as written in Article } 45 \\
\text { paragraph (1) shall be punishable by } \\
\text { imprisonment of } 6 \text { (six) years and / or } \\
\text { a maximum fine of Rp. } \\
1,000,000,000.00 \text { (one billion rupiah). }\end{array}$ & $\begin{array}{l}\text { Public regarded knew that the } \\
\text { actions were defamatory. The } \\
\text { public does not have the power to } \\
\text { perform the act of defamation. } \\
\text { Involving many parties in practice } \\
\text { and disseminating documents / } \\
\text { electronic information, including all } \\
\text { related parties from the ISP to the } \\
\text { cafe manager. } \\
\text { Careless act that is insulting and / } \\
\text { or defaming a person as well as } \\
\text { their goals and intentions } \\
\text { specifically for humiliation and / or } \\
\text { destroying the reputation of others. } \\
\text { (Source : Choiriyati, Susanto and } \\
\text { Utomo[7]) }\end{array}$ \\
\hline
\end{tabular}

Minister of Communications and Information Technology and the Commission I of the Parliament held a working meeting discusses bill to amend Law No.11 / 2008 on Information and Electronic Transactions (ITE). The meeting of the Communications and Information Technology approved a contempt charge included in the revision of Law No. 11 of 2008 on Information and Electronic Transactions. Crucial article in the revision of the ITE Law, namely Article 27, paragraph 3 related penalty of defamation. Revisions was based on the previous ITE Law stating that the threat of punishment for defamation was six (6) years in prison, but in order to eliminate multiple interpretations, the government lowered the sentence to four (4) years. In terms of the offense was to a complaint, there are reports of previous rapporteurs but before it was a common offense.

Law No. 11 of 2008 on Information and Electronic Transactions completed in June 2016 or during the fifth session in the trial from 2015 to 2016. On May 30, 2016 ITE Law revision bill is final and early June brought to the plenary to be passed into the bill and then submitted to the government. Efforts by the government to make revision deserve our appreciation, given the victims of peoples related to the implementation of ITE Law since the case of Prita Mulyasari became a controversy and turmoil in society. Further, this law is considered to limit the right to freedom of expression, speech and could inhibit creativity in to the internet, particularly in article 27 paragraph (1), Article 27 paragraph (3), Article 28 paragraph (2), and Article 31 paragraph (3).

Such articles considered to embody the rules inheritance rubber article (haatzai artikelen), because it is flexible, subjective and highly dependent on the interpretation of the ITE Law users. Criminal threats to all three were serious namey 6 years imprisonment and / or a maximum fine of 1 billion rupiah. Moreover, in the context of a criminal, all the three offenses are categorized as a formal offense, so no need to prove the effect for there has been perfect due to be considered criminal acts. In the past, the provision of this 
formal offense was often used to ensnare statements that are criticisms.

For active cyberspace users, these chapters are still disputed by some Indonesian bloggers. Something that is quite controversial and unmonitored by the government to urgently revised is ITE Law which is still loaded with an unformulated standard by default. Some of those are standards of decency, definition of gambling, and interpretation of an insult. So the question that arises then who is entitled to assess that standard? This is in line with a major controversy in the discussion of anti-pornography laws. When we review the aspects of legal jurisdiction then there are aspects that have not been refined. There is a supposition when a citizen makes pornography software out of country, he can be free from prosecution. Unfortunately, in the discussion of the ITE Law revision, the government and Parliament in this regard Commission I do not try to gradually map out the weaknesses and coherence of public interpretation on the articles of the ITE Law No. 11 of 2008.

Some minor findings in the above interpretation can be reflected on research Kitlley [8], 2000, which classifies Indonesia as a country that does not have a legal umbrella policy of clear communication, precision related to formal state relations and corporate sectors in the field of broadcasting. But it is also apparent in the case in several other Asian countries, for example, a website of www.remotivi.or.id [9]' which is active as a driver of literacy media that is critical to the regulation expressed about the state of media regulation in the Philippines. Currently there are no laws of the press in the Philippines. In their constitution, there is such a First Amandement of US Constitution. That means, freedom of the press is recognized by the state. Philippines still lags behind Indonesia accounted for another regulatory affairs, for example, legislation of FOI (Freedom of Information). Indonesia already has the Information Commission, even already approved Law No. 14 of 2008 on Public Information, while the Philippines has not had until now.

\section{CONCLUSION}

Various issues that arise in the interpretation of the coherence of communication policy comes down from no occurrence of a fundamental change in all aspects of communications regulation in Indonesia. Broadcasting Law No. 32 of 2002 was considered non-responsive in facing the competition in the country's broadcasting industry. While the government is not rushing to make revisions in the law as urgency. Not to mention when we look at the reality in the country, many businessmen from the broadcasting industry continued to show an attitude of opposition in the form of rejection. It could even be said to be attempting to not comply with the Act's decision, at least, judging from the level of regulation in Asia. Our regulatory system is relatively better. The public should continue to provide evaluation and control of communications policy in Indonesia that serves as a task of the government in this case the Ministry of Communication and Information Technology. The government must address the dynamic progress of the national information and communication systems comprehensively ranging from regulatory, legal instruments to public participation. ITE Law 11 of 2008 which has entered the stage of the revision in May 2016, will continue to be tested with the increasing complexity of technology convergence in the new media.

\section{ACKNOWLEDGMENT}

The authors express our sincere gratitude to the parties who have helped resolve this script writing as relatives and friends, and to the committee of ICONEG who has given us the opportunity to publish this paper.

\section{REFERENCES}

[1] Abrar, Ana Nadhya, Kebijakan Media Interaktif: Belum Melancarkan Sistem Komunikasi Indonesia, Junal Ilmu Komunikasi, Volume 5, Nomor 1, Juni 2008 (Abrar, Ana Nadhya, Policy of Interactive Media: It doesn't reinforce Indonesia Communication System, Communication Sceince Journal, Vol. 5, No 1, June 2008).

[2] Ricoeur, Paul, Hermeneutics and The Human Sciences Essay on Languange, Action and Interpretation, Cambridge University Press,Cambridge, 1981, p.43

[3] Palmer, Richard E, Hermeneutika: Teori Baru Mengenai Interpretasi, Pustaka Pelajar, Yogayakarta, 2003, p.8 (Palmer, Richard, Hermeneutics: New Theory about Interpretation, Pustaka Pelajar, Yogyakarta, Indonesia, 2003, p.8).

[4] Bleicher, Josef, Hermeneutika Kontemporer: Hermeneutika sebagai Metode, Filsafata dan Kritik, Fajar Pustaka Baru, Yogyakarta, 2007, p.159 (Bleicher, Josef, Contemporary Hermeneutics: Hermeneutics as Methods, Philosophy, and Critics, Fajar Pustaka Baru, Yogayakarta Indonesia, 2007, p.159).R. Nicole, "Title of paper with only first word capitalized," J. Name Stand. Abbrev., in press.

[5] Wahyuni, H.I., Ekonomi Politik Kebijakan Penyiaran Indonesia: Aspirasi, Pilihan dan Realitas, Jurnal Kebijakan dan Administrasi Publik, Volume 10, Nomor 2, November 2006, pp.149-170 (Wahyuni, H.I, Political Economy of Broadcasting Policy in Indonesia: Aspiration, Choices and Reality, Journal of Policy and Public Administration, Vol 10, No 2, November 2006, pp.149-170).

[6] Chakravartty, Paula and Katharine Sarikakis, Media Policy and Globalization, Edinburgh University Press, Edinburgh, 2006, p.7

[7] Choiriyati, Wahyuni, Leo Susanto dan Ficky Utomo, Siapa Boleh Bicara di Media Sosial? Studi Hermeneutika UU ITE dalam Konteks Kebebasan Berekspresi, Prosiding Indonesia Media Research Awards and Summit, Yogyakarta, 2015, pp.82-102 ISBN: 978-602-96140-4-6 (Choiriyati, Wahyuni, Leo Susanto and Ficky Utomo, Who Could Speak in Social Media? Hermeneutics Study of Act No. 112008 in context of freedom of expression, Proceeding Indonesia Media Research Awards and Summit Yogyakarta, 2015, pp 82-102, ISBN: 978-602-96140-4-6).

[8] Kitley, Philip, Konstruksi Budaya Bangsa di Layar Kaca, ISAI, LSPP dan Media Lintas Inti Nusantara, Jakarta, 2000, p.25 (Kitley, Philip, Construction of Nation's Culture on Screen, ISAI, LSPP and Media Lintas Inti Nusantara, Jakarta, 2000, p.25).

[9] ${ }^{10}$ Kitley, Philip, Konstruksi Budaya Bangsa di Layar Kaca, ISAI, LSPP dan Media Lintas Inti Nusantara, Jakarta, 2000, p.25 (Kitley, Philip, Construction of Nation's Culture on Screen, ISAI, LSPP and Media Lintas Inti Nusantara, Jakarta, 2000, p.25).

[10] ${ }^{11}$ Eko Maryadi: MEA dan Media di Asia Tenggara Punya Problem yang Berbeda, dapat diakses pada http://www.remotivi.or.id/wawancara/255/Eko-Maryadi:-MEA-danMedia-di-Asia-Tenggara-Punya-Problem-yang-Berbeda diakses pada 22 Agustus 2016 (Eko Maryadi: MEA and Media in Southeast Asia have different problem, can be accessed on http://www.remotivi.or.id/wawancara/255/Eko-Maryadi:-MEA-danMedia-di-Asia-Tenggara-Punya-Problem-yang-Berbeda accessed on August 22 ${ }^{\text {nd }} 2016$ ) 